\title{
Side Effects Experience on Behavior of Pregnant Women Consuming Iron Tablets
}

\author{
Istiana Intan'); Munayarokh²) Siti Rofi'ah ${ }^{3)}$ \\ istianaintan07@gmail.com
}

\begin{abstract}
Background: Anemia was a disease that attracts worldwide concern and was a very big problem, especially in developing countries. The factor that caused high iron deficiency anemia in pregnant women was the low compliance of pregnant women in consuming iron tablets. Side effects in the form of nausea were the reason pregnant women did not comply with Iron tablets. The purpose of this study was to determine the relationship between the side effects experience and the behavior of pregnant women in consuming Iron tablets. This type of research was quantitative with analytic survey and using a cross sectional approach.

Methods: This type of research was quantitative with analytic survey and using a cross sectional approach. The population in this study were pregnant women in the second and third trimesters in the working area of the Puskesmas Tempuran, Magelang Regency based on the February-March 2019 cohort, totaling 177 pregnant women with a sample of 123 pregnant women, calculated using the Slovin formula. The sampling technique used Proportionate Stratified Random Sampling. Data analysis used Kendall tau test.

Results: The results showed that most of the pregnant women who consumed Iron tablets had side effects experience caused by the behavior of pregnant women in consuming Iron tablets, mostly in the low category. Conclusion: There was a relationship between the side effects experience and the behavior of pregnant women in consuming Iron tablets. It was recommended that pregnant women consume Iron tablets regularly in accordance with the recommendations of health workers so that they can prevent anemia.
\end{abstract}

Keyword : Side Effects; Behavior; Iron Consume Tablets

\section{1,2,3) Poltekkes Kemenkes Semarang, Indonesia \\ Jl. Tirtoagung, Pedalangan, Banyumanik}

Background. Anemia was a disease that attracts worldwide concern and was a very big problem, especially in developing countries. According to the World Health Organization, the prevalence of pregnant women experiencing iron deficiency anemia was around $35-75 \%$ which increases with increasing gestational age. While the percentage of pregnant women from poor families continues to increase with increasing gestational age in the first trimester (as much as $8 \%$ ), the second trimester by $12 \%$, and the third trimester by $29 \%$ (Fatmah, 2014).

Based on (Badan penelitian dan Pengembangan Kesehatan Kementerian Kesehatan Rl, 2018) The prevalence rate of anemia in pregnant women was $48.9 \%$ with the highest number of anemia in pregnant women ranging from 15-24 years of age, while in 2013 the prevalence rate of anemia in pregnant women was $37.1 \%$. This has increased by $11.8 \%$. The prevalence of anemia based on the location of residence showed that living in rural areas has a higher percentage $(22.80 \%)$ than living in urban areas (20.60\%). If anemia was not treated seriously, it will affect the mother and baby, which can cause abortion, premature labor, obstruction of fetal growth and development in the womb, bleeding and PROM (Milda, 2016)

The government's efforts in realizing the health of pregnant women awere manifested in the provision of Antenatal Care (ANC) services at least 4 times during pregnancy (K4). Efforts were made to provide ANC services in order to meet the standard of giving blood added tablets (iron tablets) of at least 90 tablets during pregnancy, as well as simple laboratory test services at least a blood hemoglobin $(\mathrm{Hb})$ test. Providing blood-supplemented tablets was an important and effective way because it can prevent and overcome anemia due to iron or folic acid deficiency (Badan penelitian dan Pengembangan Kesehatan Kementerian Kesehatan Rl, 2018)

Pregnant women suffering from mild to severe anemia in Magelang Regency in 2017 reached $20.3 \%$ of pregnant women who were checked for hemoglobin levels. In particular, the Tempuran puskesmas, Magelang 
Regency, in 2017 the number of anemia pregnant women was $58.3 \%$ of pregnant women who were checked for hemoglobin levels. If anemia was not treated seriously, it will affect the mother and baby, including causing abortion, preterm labor, obstruction of fetal growth and development in the womb, bleeding and PROM (Milda, 2016).

According to research (Angrainy, 2017) the most common cause of anemia in pregnancy was iron deficiency. Iron deficiency can be caused by insufficient entry of iron in food, resorption disorders or because too much iron leaved the body and will inhibit the formation of hemoglobin. resulting in anemia in pregnant women. Some literature said that iron needs were twice the pre-pregnancy requirements. This happened because during pregnancy, blood volume increased by $50 \%$ (Hidayah and Anasari, 2012)

One of the factors causing the high iron deficiency anemia in pregnant women was the low compliance of pregnant women in consuming iron tablets. As many as $74.16 \%$ of pregnant women were declared non-compliant in consuming iron tablets. The main reasons for pregnant women who do not drink or spend iron tablets during pregnancy were dislike, nausea or vomiting due to the pregnancy process, boredom, forgetfulness, side effects, and it's not over yet (Badan penelitian dan Pengembangan Kesehatan Kementerian Kesehatan RI, 2018)

A preliminary study conducted by researchers showed that the fulfillment of Iron tablets at the Tempuran Public Health Center in Magelang Regency was quite good, namely 90.64\%. (Magelang, 2016). However, the compliance coverage of Iron tablets consumption in pregnant women was still low, this was evidenced by the 10 pregnant women obtained by 8 pregnant women (80\%) consuming Iron tablets regularly on the grounds of forgetting and the odor caused by Iron tablets. Based on this, the authors were interested in knowing the relationship between the side effects experience and the mother's behavior in consuming blood supplemented tablets.

Methods. This type of research was quantitative with analytic survey and used a cross sectional approach. The population in this study were pregnant women in the second and third trimesters in the working area of the Puskesmas Tempuran, Magelang Regency based on the February-March 2019 cohort, totaling 177 pregnant women. The sample size was calculated using the Slovin formula and obtained a sample of 123 pregnant women. The sampling technique used Proportionate Stratified Random Sampling based on inclusion and exclusion criteria. The inclusion criteria in this study were pregnant women in the second and third trimesters, had consumed Iron tablets, lived in the Puskesmas Tempuran area and were willing to be respondents. The exclusion criteria were mothers with hyperemesis gravidarum. Data analysis used the Kendall tau test (Dahlan, 2019).

\section{Result and Discussion.}

Table 1. Frequency distribution of pregnant women based on experiences of pregnant women who consume Iron tablets

\begin{tabular}{lll}
\hline Category & Total & $\begin{array}{l}\text { Percentage } \\
(\%)\end{array}$ \\
\hline Side Effect & 92 & 74,8 \\
No side effect & 31 & 25,2 \\
Total & $\mathbf{1 2 3}$ & $\mathbf{1 0 0}$ \\
\hline
\end{tabular}

Based on Table 1, it can be seen that after consuming Iron tablets, most of the pregnant women felt side effects as much as $74.8 \%$. Most of the side effects were nausea. In addition, side effects that can arise were vomiting and difficulty defecating. The research of Simbolon et al, (2018) stated that side effects such as discomfort in the gut, nausea, vomiting and diarrhea. This condition can be overcome by consuming iron tablets at night before bed or reducing the dosage of iron tablets from $1 \times 1$ tablet a day to $2 \times 1 / 2$ tablets a day and consuming green vegetables to facilitate bowel movements.

Side effects that are felt by pregnant women after consuming Iron tablets were common things experienced by most pregnant women and were not dangerous things. This was in accordance with the research of Lamsaputri et al, (2018) which states that the side effects of blood-supplemented tablets are nausea, vomiting, bad stomach, difficulty defecating and black stools, but this is not dangerous. For pregnant women who feel the effect of nausea from the Iron tablets themselves, they can consume blood booster tablets regularly at night to get used to or reduce the nausea caused by Iron tablets. In the study, it was also stated that respondents 
who took blood booster tablets once a week for not menstruating, every day during menstruation and after being interviewed, respondents said that taking blood supplement tablets regularly can relieve nausea which was a side effect of the blood added tablets.

The compliance condition for consuming Iron tablets was also influenced by experiences in previous pregnancy. Multipara has experience consuming Iron tablets in previous pregnancies, so she had experienced side effects after consuming Iron tablets. This was related to the results of research by Ana Samiatul Milah, (2018) which states that multigravida mothers have experience from previous pregnancies or childbirth. Respondents thought that their pregnancy had no complications so they were reluctant to take Iron tablets

Table 2 The frequency distribution of respondents based on the behavior of pregnant women in consuming Iron tablets

\begin{tabular}{lll}
\hline Category & Total & $\begin{array}{l}\text { Pecentage } \\
(\%)\end{array}$ \\
\hline Mot Good & 69 & 56,1 \\
Good & 54 & 43,9 \\
Total & $\mathbf{1 2 3}$ & $\mathbf{1 0 0}$ \\
\hline
\end{tabular}

Based on table 2 it is known that pregnant women who have poor behavior and who have good behavior in consuming Iron tablets have almost the same percentage, namely $56.1 \%$ and $43.9 \%$

Pregnant women who had poor behavior in consuming Iron tablets in the study were probably due to laziness and side effects. This was in accordance with the research of Lamsaputri et al, (2018) regarding the effect of counseling with assistance on the behavior of young women to drink virgin added tablets at SMP N 8 Mataram which states that the average number of blood-added tablets consumed by young women was only 4 tablets out of the total. at most 10 tablets. Lack of consumption of Iron tablets was caused by teenage girls who often forget to take blood booster tablets and complain about the side effects that arise in the form of nausea after consuming the tablets.

According to Notoatmodjo, (2014) health care behavior was a healthy behavior that arises because of one's efforts to maintain or maintain health so as not to get sick and was also related to one's efforts or activities to maintain and improve one's health or a healthy lifestyle. The lack of behavior in consuming Iron tablets, can be because most of the respondents were multiparous so that they have experience consuming Iron tablets in previous pregnancies, so they have experienced side effects after consuming Iron tablets. This affects the behavior of consuming Iron tablets in the current pregnancy. This was related to the research of Marlina, (2019) that there were various factors that influence healthy behavior. Experience or previous history of disease that has been experienced by an individual can influence his behavior. Beliefs or values held by a person related to health will influence him to behave in a healthy manner.

Pregnant women who consume Iron tablets irregularly can result in a lack of iron in the body which will cause the risk of anemia. This research was supported by the results of research by Ana Samiatul Milah, (2018) which states that someone who consumes Iron tablets irregularly could caused iron to not be absorbed optimally and would caused anemia in pregnant women so that more pregnant women do not regularly consume. Iron tablets had a higher risk of anemia.

Table 3 The Relationship between Experience and Side Effects of Pregnant Women Behavior in Consuming Iron tablets

\begin{tabular}{lllll}
\hline kategori & \multicolumn{2}{l}{$\begin{array}{l}\text { Behavior } \\
\text { Not Good }\end{array}$} & Good & Total \\
\hline Side & $f$ & 60 & 32 & \\
Effect & $\%$ & 65.2 & 34.8 & 100 \\
No Side & $f$ & 9 & 22 & \\
Effect & $\%$ & 29.0 & 71.0 & 100 \\
\hline
\end{tabular}

$p$ value : 0,000

Based on table 3 it can be seen that respondents who behave less and have side effects experience have a greater percentage of $65.2 \%$ compared to respondents who do not have experience of $29.0 \%$, while respondents who behave well and have side effects experience have a higher percentage of $34.8 \%$ compared to respondents who have no experience $71.0 \%$. Thus, pregnant women who have experienced side effects and do not tend to have less behavior in consuming Iron tablets.

The results of the analysis of the relationship between experience and the behavior of pregnant women in consuming Iron 
tablets were tested using the Kendal Tau formula, the correlation coefficient value was 0.317 , which means that it had a weak interpretation of the relationship because it was in the range $0.2-0.4$ and the $p$ value was 0.000 (0.000). <0.05), then alternative hypothesis was accepted which indicates that there was a relationship between the attitudes of pregnant women and the behavior of pregnant women in consuming Iron tablets in the working area of the Puskesmas in Tempuran.

The result of statistical analysis showed that there were a relationship between experience and behavior of pregnant women in consuming Iron tablets. The results of this analysis were supported by descriptive analysis that pregnant women who have experienced side effects tend to have less behavior in consuming Iron tablets. In line with the research of Hadiyani \& Yunidha, (2019) which states that the presence of nausea and even vomiting after consuming Iron tablets will affect maternal compliance in consuming Iron tablets.

Most of the respondents were multiparous who had experienced the side effects of consuming Iron tablets in the form of nausea in previous pregnancies, so that mothers were lazy to consume iron tablets again. This was in line with the results of research by Ana Samiatul Milah, (2018) which states that multigravida mothers had experience from previous pregnancy or childbirth. Respondents thought that their pregnancy had no complications so they were reluctant to take Iron tablets

Pregnant women who experience side effects in the form of nausea when consuming Iron tablets in previous pregnancies will affect the behavior of consuming Iron tablets in their current pregnancies. Side effects caused by Iron tablets include nausea, vomiting, and difficulty in choking, this was normal for some pregnant women and was not a dangerous thing.

According to Simbolon et al, (2018) to overcome nausea after consuming Iron tablets, namely by consuming iron tablets at night before going to bed or reducing the dose of iron tablets from $1 \times 1$ tablet a day to $2 \times 1 / 2$ tablets a day using plain water or drinks contains vitamin $\mathrm{C}$ to accelerate the absorption process of iron tablets itself and consume green vegetables to facilitate bowel movements. According to research by Ana Samiatul Milah,
(2018) states that vitamin C plays a very important role in increasing the absorption of iron in the body. Increasing the consumption of vitamin $\mathrm{C}$ by $25-250 \mathrm{mg}$ can increase iron absorption 2-5 times.

Conclusion and Suggestions. Most of the pregnant women who consume Iron tablets have experienced side effects caused by the behavior of pregnant women in consuming Iron tablets. Most of them were in the low category. There was a relationship between the side effects experience and the behavior of pregnant women in consuming Iron tablets. It was recommended that pregnant women consume Iron tablets regularly in accordance with the recommendations of health workers so that they can prevent anemia

Acknowledgements. Thanks to the researchers say to all those who have helped in completing this research.

\section{References}

Ana Samiatul Milah. 2018. 'Hubungan Konsumsi Tablet Fe Dengan Kejadian Anemia Pada Ibu Hamil Di Desa Baregbeg Wilayah Kerja Puskesmas Baregbeg Kabupaten Ciamis Tahun 2018', Jurnal Keperawatan Galuh, pp. 12-36.

Angrainy, R. 2017. 'Hubungan Pengetahuan Dengan Sikap lbu Hamil Dalam Pencegahan Anemia di Puskesmas Rumbai', Journal Endurance, 2(1), pp. 6267. doi: 10.22216/jen.v2i1.1654.

Badan penelitian dan Pengembangan Kesehatan Kementerian Kesehatan RI. 2018. Laporan Nasional Riskesdas 2018. Jakarta.

Dahlan, M. sopiyudin. 2019. Besar Sampel dalam Penelitian Kedokteran dan Kesehatan. 5th edn. Jakarta: Epidemiologi Indonesia.

Fatmah. 2014. Gizi dan Kesehatan Masyarakat. Jakarta: Raja Grafindo Persada.

Hadiyani, W. and Yunidha, V. 2019. 'Pengaruh Kepatuhan Konsumsi Tablet Fe Terhadap Kadar Haemoglobin Ibu Hamil', jurnal kebidanan, 003. 
Hidayah, W. and Anasari, T. (2012) 'hubungan Kepatuhan Ibu Hamil Mengkonsumsi Tablet Fe Dengan Kejadian Anemia Di Desa Pageraji Kecamatan Cilongok Kabupaten Banyumas', jurnal ilmiah kebidanan, 3(2), pp. 41-53.

Lamsaputri, N. et al. 2018. 'Pengaruh Penyuluhan dengan Pendampingan terhadap Perilaku Remaja Putri Minum Tablet Tambah Darah di SMPN 8 Mataram Tahun 2018 The Influence of Counseling with Assistance to the Adolescent Girls ' Behavior of Drinking Blood Add Tablets at SMP 8 Mataram'.

Magelang, D. K. 2016. 'Profil Kesehatan Kabupaten Magelang Tahun 2016', pp. 1147.
Marlina, A. 2019. 'Pengaruh Kepatuhan Ibu Hamil Dalam Mengkonsumsi Tablet Zat Besi Di Wilayah Kerja Puskesmas Muara Dua Lhokseumaawe', 2(1), pp. 43-50.

Milda, I. 2016. Nutrisi Pintar Ibu Hamil Dan Menyusui Untuk Golongan Darah $A B$. jakarta: bhuana ilmu populer.

Notoatmodjo, S. 2014. Promosi Kesehatan dan perilaku Kesehatan. Jakarta: Rineka Cipta.

Simbolon, dr. demsa, Jumiyati and Rahmadi, A. 2018. pencegahan dan penanggulangan kurang energi kronik (KEK) dan anemia pada ibu hamil. yogyakarta: deepublish. 